\title{
Cotidiano
}

Alexandre Freitas Marchiori' Ana Gláucia do Carmo Silva²

\section{Brincar e aprender: uma experiência de práticas pedagógicas com crianças de cinco anos no CMEl Dr Denizart Santos}

\author{
A tarefa principal do professor: seduzir o aluno para que \\ ele deseje e, desejando, aprenda (Rubens Alves).
}

Introdução

Por que essa prática merece ser compartilhada? Cremos ser este o ponto principal deste trabalho. Há algum tempo temos buscado relatos de experiências que nos ajudem a pensar o fazer docente na educação infantil e foi possível encontrar trabalhos cada vez mais elaborados, condizentes com uma proposta que reconhece as especificidades do trabalho educacional com crianças de zero a seis anos. Neste sentido, pretendemos colaborar com essa produção ao compartilhar essa experiência de educação das/com as crianças, superando um modelo assistencial ao reconhecer as aprendizagens vivenciadas pelas crianças, e com elas, no último ano na instituição, pois esse ciclo de aprendizagem se encerra no Grupo VI na rede municipal de Vitória.

O preparo para o ensino fundamental não foi o "carro-chefe", mas o reconhecimento que esse tempo da educação infantil deve ser único. Entretanto, sabíamos que eles sairiam do CMEI e começariam uma nova etapa em suas vidas. Então, se não é um preparo, deve ser o quê? O que as crianças podem aprender e de que forma nós professores podemos contribuir com a formação delas? Com a saída da criança de seis anos da educação infantil ${ }^{3}$, houve necessidade de adequações tanto dos conteúdos quanto na metodologia empregada na condução pedagógica do Grupo VI. Não significou simplesmente manter as práticas com as crianças de 5 anos, mas repensar esse momento de

I Mestre em Educação pelo Programa de Pós-Graduação em Educação - PPGE da Universidade Federal do Espírito Santo. Professor de Educação Física. Prefeitura Municipal de Vitória - PMV.

2 Professora Regente. Prefeitura Municipal de Vitória - PMV.

3 A Lei no 11.274, de 6 de fevereiro de 2006 - amplia o Ensino Fundamental para nove anos de duração, com a matrícula de crianças de seis anos de idade e estabelece prazo de implantação, pelos sistemas, até 2010. A Resolução 05/2009, no seu artigo $5^{\circ}$ diz que a Educação Infantil deve oferecer educação e cuidado às crianças de 0 a 5 anos de idade no período diurno, em jornada integral ou parcial. No seu parágrafo $2^{\circ}$ diz que a matrícula é obrigatória para as crianças que completam 4 ou 5 anos até o dia 3 I de março do ano em que ocorrer a matrícula. O parágrafo $3^{\circ}$ propõe que as crianças que completam 6 anos após o dia 31 de março devem ser matriculadas na Educação Infantil. 
finalização do ciclo da educação infantil e a saída delas para o Ensino Fundamental. Então, quais conteúdos podem e devem ser trabalhados com crianças de cinco anos? Essas questões ecoaram nas práticas educativas que aconteceram no CMEI Denizart Santos em 2012, sendo este relato um fragmento.

Este relato de experiência só foi possível devido o registro sistemático do planejamento da professora regente em um caderno, no qual constam os planejamentos das aulas, as reflexões da professora Ana Gláucia, alguns registros das falas das crianças, a produção textual delas, algumas atividades desenvolvidas, acontecimentos não planejados e as duas avaliações individuais que foram produzidas em 2012. O registro fotográfico também foi outra fonte de pesquisa.

A turma era composta por um grupo de 16 (dezesseis) crianças de cinco a seis anos, atendidas por 01 professora regente e 01 estagiária. A sala permitia um quantitativo de 25 alunos, porém, a demanda do bairro e vizinhança havia sido suprida para essa faixa etária. Eram seis meninos e 10 meninas, cada um com sua história de vida e experiências sócio-educativas. Havia uma aluna com necessidades educativas especiais (surdez), pois essa instituição é referência na rede municipal com o trabalho bilíngue. Neste sentido, aconteciam aulas e acompanhamentos com uma professora de libras e uma interprete surda durante a rotina do CMEI.

A rotina do CMEI Denizart Santos (DS), localizado no bairro Ilha do Príncipe no município de Vitória/ES, inclui aulas de 50 minutos com 02 professores de educação física, 01 professora de artes. Assim que esses profissionais assumem a turma, a professora tem esse tempo garantido para planejamento, num total de 05 por semana. É possível contar com 01 pedagoga para acompanhar essa turma ao longo do ano, participando dos planejamentos, execução das aulas, problemas no comportamento/relacionamento na instituição, interação com a família e avaliação. O laboratório de informática, com uma estagiária responsável pelo funcionamento e execução dos trabalhos em parceria com a professora regente, também foi outro espaço utilizado pelas crianças.

\section{O Projeto institucional e o Projeto de sala}

O projeto institucional "Cantando e brincando com a sustentabilidade" foi escolhido pelo grupo de profissionais do CMEI Denizart Santos para nortear as práticas e intervenções em todas as turmas da instituição. Cada professor(a), com apoio das pedagogas, apresenta um projeto para ser desenvolvido durante o semestre ou anual. O Grupo VI, sob a responsabilidade da professora Ana

4 Essa profissional só passou a fazer parte da rotina das crianças no segundo semestre, auxiliando a professora na sala de aula e rotinas do CMEl. Também acompanhava os professores de arte e educação física nas aulas na sala de artes e no pátio. 
Gláucia, desenvolveu o projeto de sala "Eu brinco, canto e quero um mundo sustentável”.

Diante desse tema, a professora propôs trabalhar a partir do brincar como ação propulsora do aprender. Os brinquedos e as brincadeiras na escola fizeram parte da estratégia adotada em 2012. Neste sentido, a cada duas vezes no mês as crianças traziam para a sala um brinquedo para socializar com os colegas. Consistia na apresentação do brinquedo, escrita do nome dos brinquedos no quadro, trabalhar a matemática (contagem), conversa sobre cada um dos artefatos, fazer uma lista e efetuar a leitura. A rotina se encerrava após brincarem e trocarem os brinquedos livremente, com supervisão da professora.

Outra estratégia foi ocupar o corredor da instituição e possibilitar a vivência das brincadeiras pelas crianças. Mas por onde começar? A professora entendeu ser importante ouvir as crianças. Ela propõe uma pesquisa na rodinh $a^{5}$. As crianças foram convidadas a falar sobre o que entendiam sobre o brincar. Cada um falou o que entendia (achava) sobre "eu brinco".

As falas registradas foram: - É brincar de carrinho (Miguel); - É quando a mãe coloca o pano no chão e eu sento para brincar com os brinquedos (Valentine); - Quando a gente está brincando e o amigo está sem amigo, a gente chama o amigo e brinca com ele (Adrya); - Quando a gente brinca, pega a boneca da Barbie e brinca (Ana Luiza); - É brincar de fogãozinho, bicicleta e boneca da Barbie (Taliba); - É quando pega um brinquedo, senta no sofá ou na cadeirinha, pega as pecinhas, faz um carrinho ou robozinho e fica brincando (Nícollas); - Professora, a palavra parece brinco de usar na orelha (Ana Carolina); - É brincar e arrumar a bagunça dos carrinhos (Kauã); - Brincar é ficar sentado e pegar o brinquedo para brincar (Arthur); - É quando a gente está no quarto e pega as bonecas para brincar (Débora); - Eu brinco com minha irmã porque ela quer brincar comigo de brinquedo (Richard).

A professora fez uma nova pergunta: você brinca de quê? As crianças prontamente relataram que brincam com carrinhos, robô, bonecas (destaque para a Barbie) e bonecos (Max Still), dar banho no ursinho, mãe e filha e, para surpresa da professora, o aluno Kauã diz: "Bola de papel. Eu amasso o papel, coloco na sacola plástica, amarro e depois chuto". Esse material foi utilizado pela professora, expondo as falas em um cartaz na frente da sala de aula, sendo os autores devidamente identificados. Essa atividade também foi tema de uma oficina, na qual Kauã se propôs a ensinar os colegas. Após a confecção dos brinquedos foram brincar no corredor.

É importante relatar que essa conversa foi iniciada pela professora, após a leitura do texto "Os brinquedos do vovô":

5 Essa prática é comum nas instituições infantis. Consiste em dispor as crianças sentadas permitindo que todos se vejam e mantenham contato visual com a professora. Todos juntos formam um círculo ou roda. 
Lá no banco da praça o avô recorda com o neto: "que bom lembrar, meu neto, das travessuras do meu tempo de criança. Rolimã, bola, peteca, pipa, bicicleta e pião, pula-corda, cabra cega, escondeesconde, passa anel e pega-pega. Ô!...Ô!...Ô!!... São brincadeiras gostosas que divertiam o seu avô! E hoje, você, meu neto, não percebe o tempo que passa, fica no vídeo game, fechado naquela sala. Ô!...Ô!...Ô!!... Abra os olhos meu netinho, aproveite... Brinque sempre, das coisas tão diferentes, que lhe conta seu avô (Nicola e Chiarion, 1996).

Esse texto foi significativo para desenvolver as brincadeiras com as crianças. Havia desenhos de pipa, rolimã, pião, bola, peteca, corda e um "quadro" com uma criança à frente da TV jogando vídeo game. Após a leitura, a professora fez no quadro uma lista com os brinquedos que apareceram na leitura. A discussão do assunto resultou no planejamento das atividades que seriam executadas ao longo de 2012 e, consequentemente, exigiu articulação com o professor de educação física. É importante destacar que as famílias foram consultadas sobre as brincadeiras que os pais vivenciaram quando crianças. Ratificaram as brincadeiras que constam no texto, relatando outras, tais como "o pé de lata", a "perna de pau”, cabra cega, piques e outras.
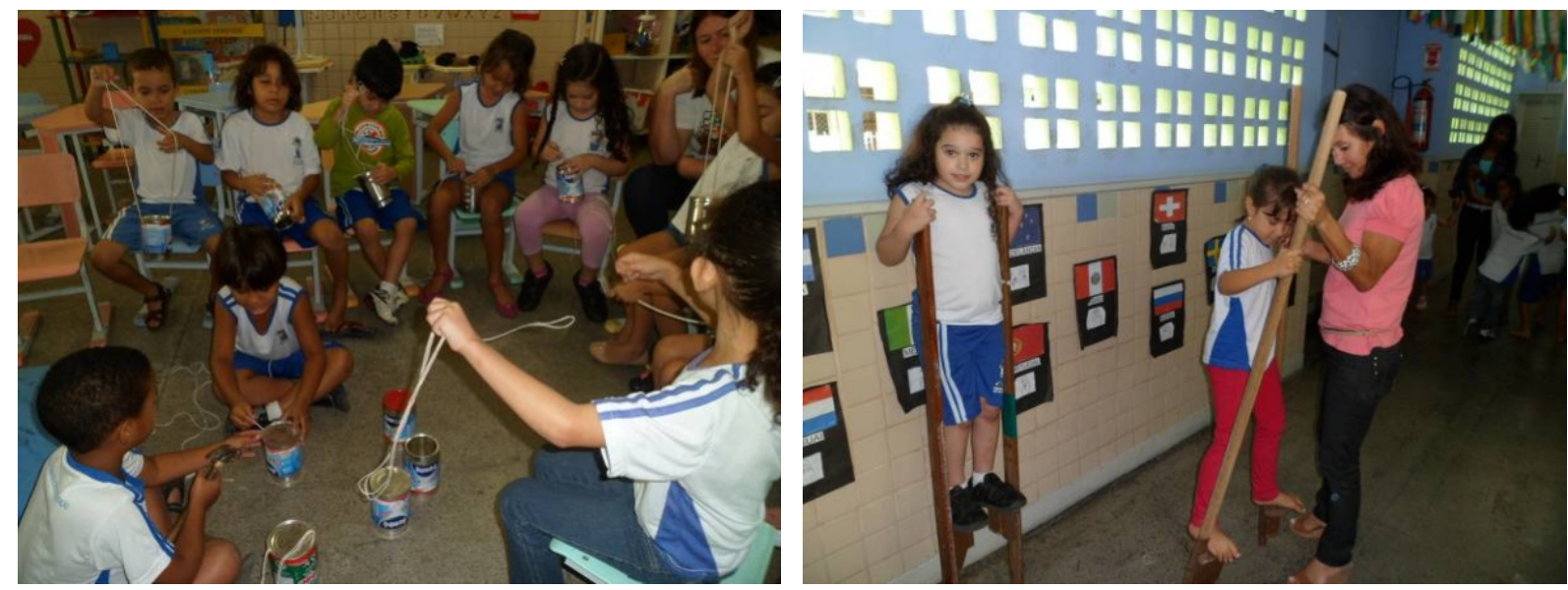

O primeiro trabalho desenvolvido foi "brincar com bolinhas de gude".

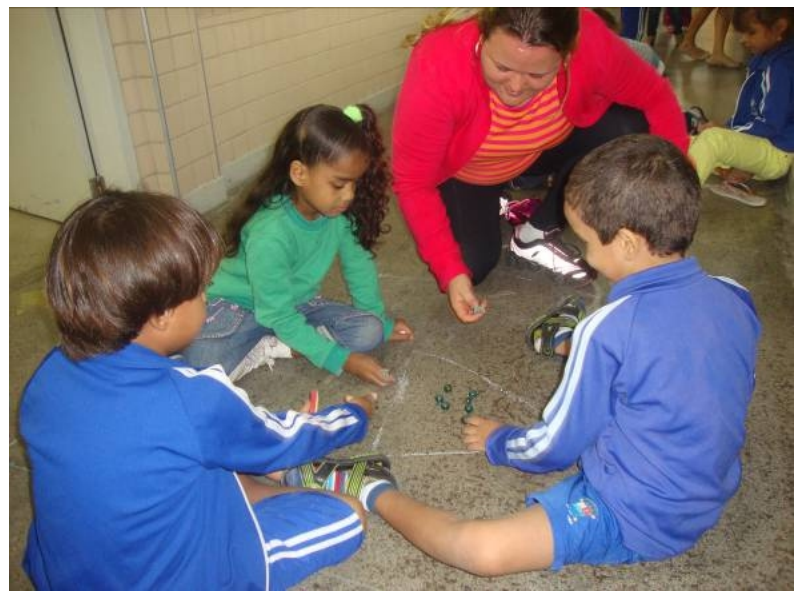


Consistiu na exploração do jogo, com o ensino das regras e explicação da forma de brincar, trabalhar quantidade, escrita na folha de cartolina e ilustração. No "corredor da brincadeira" distribuem-se as bolinhas e giz para brincarem com o material. As formas geométricas, devido a utilização do desenho do triângulo, bem como a utilização da caixa de blocos lógicos, permitiram o trabalho com a matemática.

O carrinho de rolimã foi fabricado pelo professor de educação física, sendo o processo de montagem acompanhado pelas crianças. No final, brincamos no corredor e entreguei o artefato para a professora. Ela também pediu as petecas que havia trabalhado há algum tempo no CMEI. Prontamente esse material foi disponibilizado e concordado que trabalharia com essa proposta nas aulas de educação física assim que ela utilizasse com as crianças no corredor.
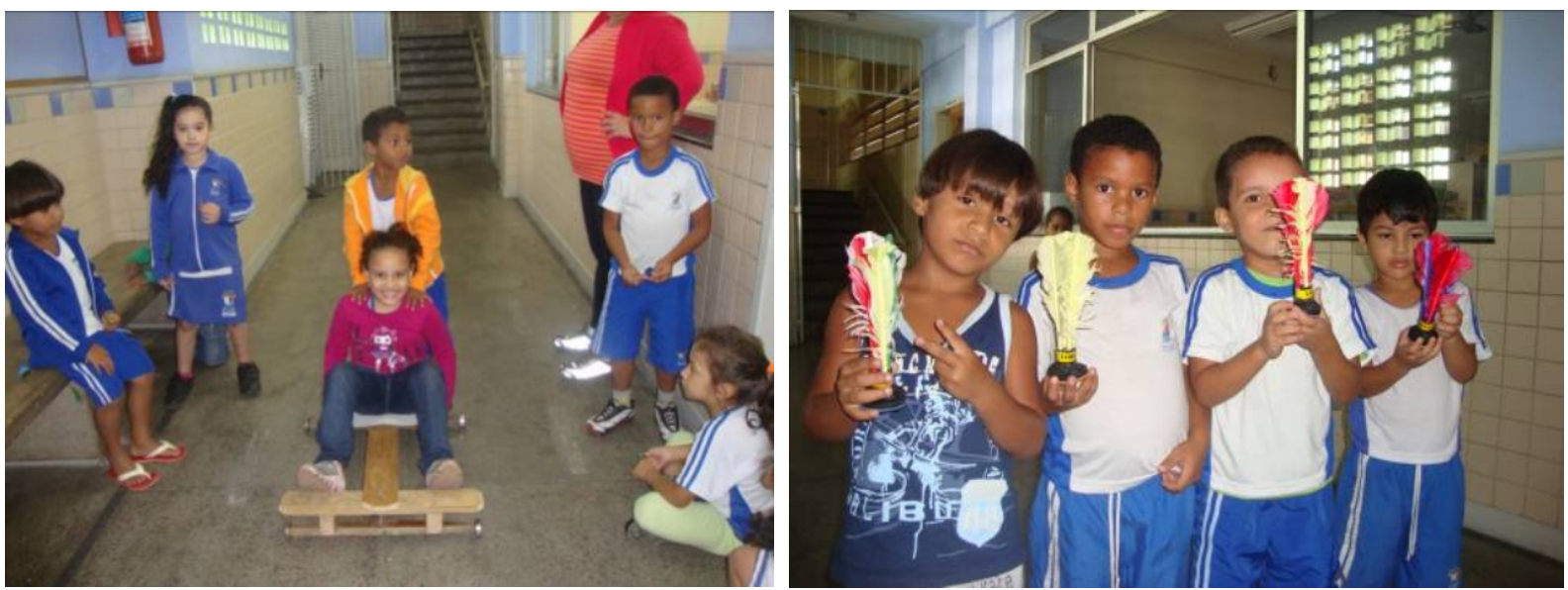

As brincadeiras ocorreram ao longo de 2012 intercaladas com a proposta educacional e exploração de outros textos e músicas, bem como o trabalho com o tema "sustentabilidade". No trabalho com cordas, mais uma vez a parceria com professor de educação física foi solicitada, pois esse material faz parte das atividades corporais/culturais que acontecem na rotina da instituição. A exploração no corredor ficou por conta da professora regente. Nesta atividade, a professora também utilizou a música "Pular corda" da Xuxa'. 

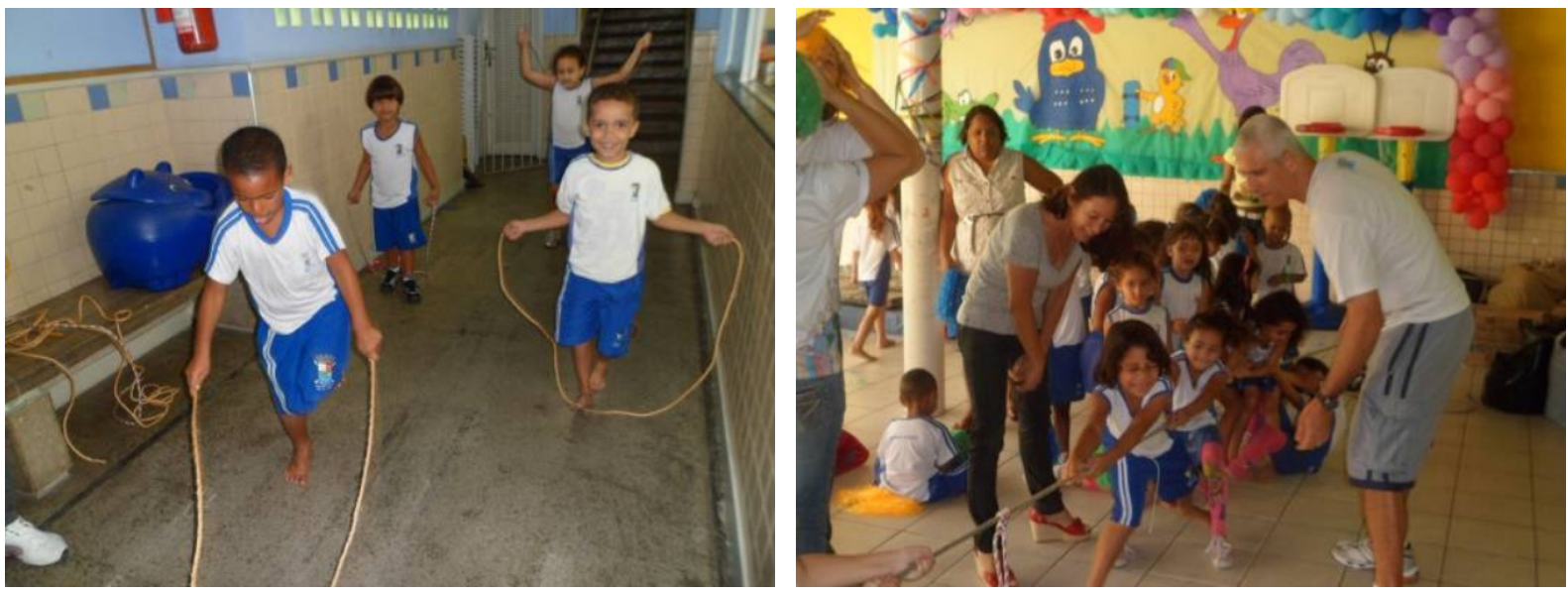

Quanto ao letramento e alfabetização, as atividades ocorreram durante todo o ano de 2012. Um dos primeiros trabalhos realizado foi a distribuição de fichas com os nomes das crianças e a utilização do alfabeto móvel. Consistia na tarefa de cada criança formar o nome de um colega, sendo à escolha da professora. Logo após, elas conferiam os nomes e se estava formado corretamente. Valentine, ao conferir seu nome, diz: "nossa, meu nome está muito confuso". Ela encontrou a letra "V" no lugar do "N". Em seguida ela ajuda a colega a corrigir.

Esse trabalho segue, dialogando-se com as brincadeiras, músicas e leituras de textos. A rotina do CMEI também servia de subsídio para a construção do saber. Atividades sequenciadas e permanentes como a escrita do nome, contagem dos alunos, destacando o número de meninos e meninas, a agenda do dia no quadro com os momentos de educação física, artes, informática permitiam um constante diálogo com as crianças, pois estas visualizavam a rotina. As crianças já esperavam essa construção coletiva e pediam a professora: - Professora, vamos fazer a agendo do dia?

Os trabalhos de sala avançam e há apropriação dos signos e símbolos culturais. Trabalha-se com a escrita das palavras "osso, ovo, olho". Segue-se à contagem das letras, ligar a palavra ao desenho, desenhar conforme a palavra escrita, recorte e colagem da letra "O" e palavras que têm a letra "O". Posteriormente, trabalha-se com o alfabeto ilustrado com as vogais (recorte das letras vogais ilustradas): $\mathrm{A}=$ Abelha, $\mathrm{E}=$ Estante, $\mathrm{I}=$ Índio, $\mathrm{O}=\mathrm{Olho}, \mathrm{U}=\mathrm{Unh}$. Segue-se com a contagem das letras, confecção das fichas com as palavras destacadas utilizadas para leitura e uso do alfabeto móvel. 


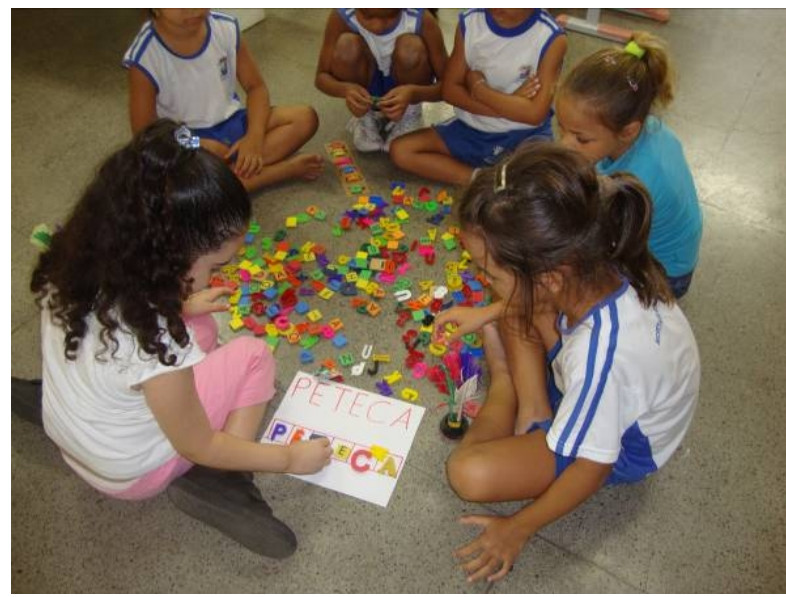

O texto "Brinquedos do vovô" desencadeia uma sequência de atividades didáticas: alfabeto móvel com as fichas, produção de um mural, pintura das palavras dos brinquedos no texto, ligar as palavras às figuras, comparar as letras iniciais dos nomes das crianças com os brinquedos, tais como: boneca, bola, boliche, escrita espontânea e "circular" palavras. A letra "B" foi desenvolvida a partir de uma história (texto) “O Barco”. As crianças fazem desenho e escrita espontânea. Após a leitura, eles fazem dobradura, escrita e ilustração, contam as letras e registram, mostram o som das letras vogais e consoantes. Posteriormente são preparadas caixas com a letra "B", dentro colocam-se as fichas com as palavras usadas em sala. Em seguida, conta-se a história da "Barata Tonta" de autoria de Maria do Carmo. Essas atividades se repetem com outras letras, sempre em diálogo com os "brinquedos do vovô" e os brinquedos que as crianças traziam para o CMEI nos dias marcados.

O tema sustentabilidade também compõe esse cenário educacional. A música, um xote ecológico com Aguinaldo Batista e Luiz Gonzaga, com tema degradação do meio ambiente, foi utilizado para introduzir esse assunto:

Não posso respirar, não posso mais nadar. A terra está morrendo, não dá mais pra plantar. Se plantar não nasce, se nascer não dá. Até pinga da boa é difícil de encontrar. Cadê a flor que estava aqui? Poluição comeu. E o peixe que é do mar? Poluição comeu. E o verde onde está? Poluição comeu. Nem o Chico Mendes sobreviveu.

Posteriormente, as crianças produziram o "Boneco Ecológico" com meia e alpiste. A letra do xote foi problematizada com as crianças. Trabalhou-se o plantar, a inga7 como um problema social, citando os problemas que a bebida causa, quem foi Chico Mendes8, o que é poluição e como o homem é o único ser vivo que polui e destrói a natureza, poluindo os rios, o ar, praias, matas, etc.

A história “Um mundo melhor", de Patrício Dugnami foi outro recurso para conversar sobre o mundo (planeta sustentável). A música "Herdeiros do futuro", de Toquinho, foi apresentada às crianças: 
Não posso respirar, não posso mais nadar. A terra está morrendo, não dá mais pra plantar. Se plantar não nasce, se nascer não dá. Até pinga da boa é difícil de encontrar. Cadê a flor que estava aqui? Poluição comeu. E o peixe que é do mar? Poluição comeu. E o verde onde está? Poluição comeu. Nem o Chico Mendes sobreviveu.

Posteriormente, as crianças produziram o "Boneco Ecológico" com meia e alpiste. A letra do xote foi problematizada com as crianças. Trabalhou-se o plantar, a pinga ${ }^{7}$ como um problema social, citando os problemas que a bebida causa, quem foi Chico Mendes ${ }^{8}$, o que é poluição e como o homem é o único ser vivo que polui e destrói a natureza, poluindo os rios, o ar, praias, matas, etc.

A história “Um mundo melhor", de Patrício Dugnami foi outro recurso para conversar sobre o mundo (planeta sustentável). A música "Herdeiros do futuro", de Toquinho, foi apresentada às crianças:

\begin{abstract}
A vida é uma grande amiga da gente, nos dá tudo de graça pra viver. Sol e céu, luz e ar, rios e fontes, terra e mar. Somos os herdeiros do futuro e para esse futuro ser feliz, vamos ter que cuidar, bem desse país. Será que no futuro haverá flores? Será que os peixes vão estar no mar? [...] Será que a vida acaba encontrando um jeito para gente ser feliz.
\end{abstract}

Também foram agendados dois passeios externos: Parque Pedra da Cebola e Planetário. Essas visitas permitiram que as crianças vivenciassem os conceitos de mundo e natureza, bem como a responsabilidade que todas as pessoas possuem em cuidar do planeta.

Outras histórias fazem parte dessa experiência docente, tais como "Dona Baratinha", de Ana Maria Machado; "Se todas as coisas fossem mãe", "A Foca famosa”, "As duas Luas", destaque para o texto "Brinquedos", de autoria de André Neves. A partir dessa leitura foi possível trabalhar conceitos: respeito, valorização, cuidado, doação, partilha (disputa), condição social das pessoas, sentimentos, trabalho infantil, além das atividades de letramento e alfabetização. Outras histórias que fizeram parte do cotidiano foram "O ratinho e a Lua", "O homem dos sete mil instrumentos" da coleção estrelinha, "Eu e minha luneta" da coleção Viagem do olhar, "A Amizade" de Teca e Nico, "A Água”, "Chico e a Água”, "A Semente e o Fruto”, "Retalhinho branco” de autoria de Maria Helena Portilho e outros.

As apresentações culturais também fizeram parte da rotina dessas crianças. As músicas "Herdeiros do Futuro" e "Ai Menina" foram temas apresentados nos momentos culturais no CMEI. Além destas, fizemos um convite às crianças do Grupo VI: se eles gostariam de cantar para os colegas no final do ano? Para isso, eles deveriam escolher algumas músicas que gostariam de cantar para ensaiarmos com o violão.

\footnotetext{
7 Nome popular da cachaça, bebida com teor alcoólico elevado, produzido a partir da cana de açúcar.

8 Chico Mendes, um ambientalista, foi morto por defender e lutar pela preservação do meio ambiente na Floresta Amazônica.
} 

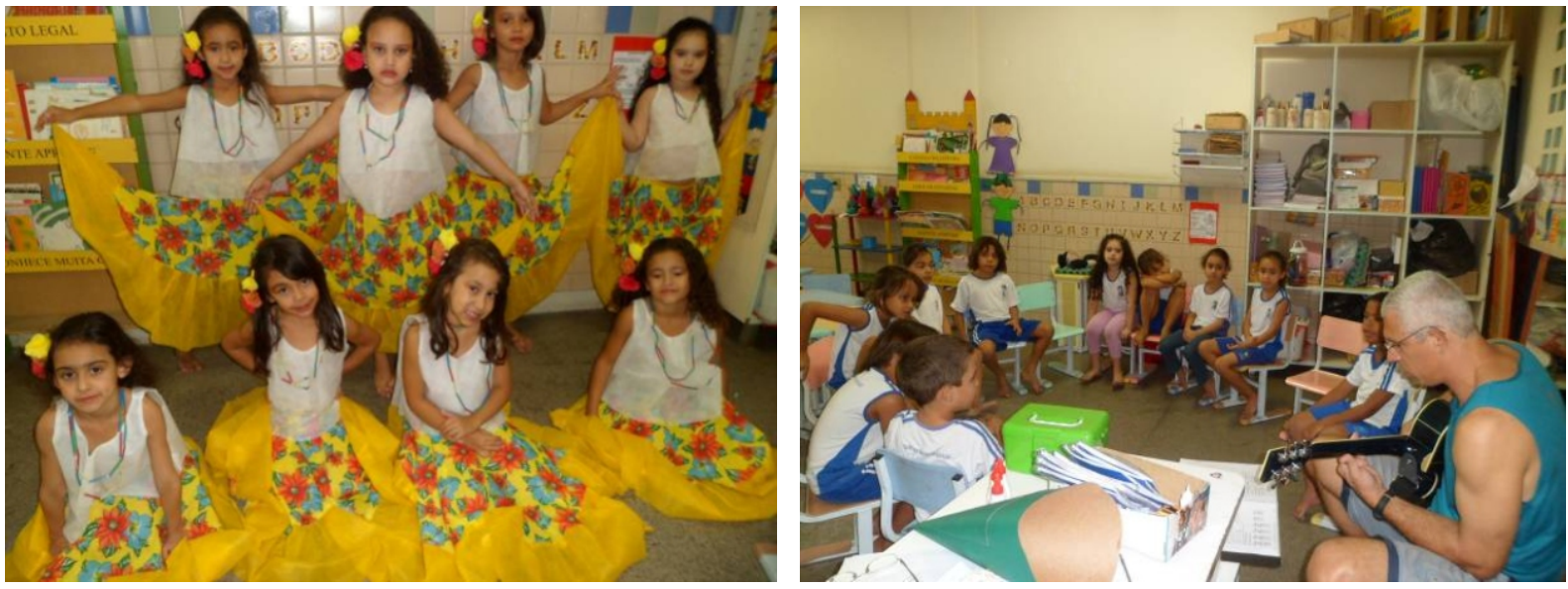

Inicialmente, a professora Ana Gláucia fez uma enquete na roda para saber as músicas escolhidas. Elas escolheram: Herdeiros do futuro - Toquinho; "Yo, yo, yo" - Novela Avenida Brasil; "Es my Love", "Vida de Empreguete" - Novela Cheias de Charme; Embarque nesse Carrossel Novela Carrossel; Amar não é pecado e Meteoro - Luan Santana; Fico assim sem você - Adriana Calcanhotto e o Natal Existe. Essas músicas foram gravadas e trabalhamos quinzenalmente, ora com o CD no rádio e ora comigo no violão. As famílias foram convidas para prestigiar essa apresentação que aconteceu no encerramento letivo.

No tocante à avaliação, como todo processo escolar exige avaliar o aprendizado das crianças, considerando que esse espaço de educação infantil possui especificidades que ultrapassam o modelo de escola, sendo, ainda, uma exigência das escolas que iriam receber os novos alunos, as avaliações seguiram um modelo argumentativo sobre o comportamento das crianças, o relacionamento entre pares, as conquistas e avanços na alfabetização (letramento), domínio da escrita, apropriação das noções de matemática (soma, quantidade, forma, sequência e outros), linguagem oral, corporal, raciocínio lógico, apropriação dos conhecimentos trabalhados no projeto e relacionamento com a família, como se pode observar na ficha avaliativa de dois alunos:

Apresenta hábitos de cortesia e sociabilidade, em situações em que se sente contrariada, permanece de braços cruzados, muito séria e às vezes chora, sendo necessária a intervenção da professora com diálogos para que possa compreender e aceitar a situação do momento. Tem bom desenvolvimento do esquema corporal e domínio do corpo, postura e equilíbrio. Participa das atividades de dramatização, danças, músicas e atividades físicas com muita desenvoltura. Se expressa com clareza e facilidade, compreende bem as orientações dadas e faz reconto de histórias lidas pela família com o projeto "Ciranda do livro". Reconhece o alfabeto e alcançou a escrita silábica com valor sonoro, percebe o som das letras para iniciar a escrita, mas às vezes demonstra insegurança para iniciar a escrita espontânea, precisando assim da mediação da professora para que possa concluir a atividade com segurança.

Seu relacionamento com os colegas está mais tranquilo, gosta de brincar com petecas e corda apenas com um colega ou sozinho. 


\begin{abstract}
Demonstra certa ansiedade, não espera a vez para falar e apresenta gagueira na fala. Em situações de leitura e escrita, reconhece e identifica as letras do alfabeto, alcançou a escrita na fase silábica alfabética, escreve palavras e compreende que a escrita é a representação da fala, porém, só inicia a escrita espontânea com mediação da professora, sua insegurança o deixa alheio ao grupo e sempre diz que não sabe, mas a partir da intervenção, realiza a atividade demonstrando compreensão. Frequenta sessões com psicóloga e neuropediatra, pois apresenta comportamento agressivo, situações de conflitos com os colegas e professores e apresentava não obedecer às normas e regras do CMEl. Hoje, está mais tranquilo no convívio com o grupo, consegue ouvir a professora nos momentos de conflito e controla seus impulsos quando incomodado pelos colegas.
\end{abstract}

A educação física também foi vivenciada por essas crianças e as parcerias com a professora regente contribuíram para ampliar os conhecimentos e as múltiplas linguagens. Os objetivos que orientaram as intervenções pedagógicas objetivaram ampliar o conhecimento e proporcionar vivências a partir da apresentação de novos conteúdos da cultura corporal, desenvolvendo algumas brincadeiras e jogos, permeados pelos conceitos de liberdade, respeito e paz. Buscou-se, também, trabalhar o conceito de "Sustentabilidade", numa perspectiva de reconhecimento humano integrado à concepção de meio ambiente, como nos propõe Romesín e Dávila Y (2004, p.107):

\begin{abstract}
Ximena: A noção de sustentabilidade, na dinâmica da vida humana, só se atualiza na conservação das condições que fazem possível este habitar. Maturana: Então, se desejamos produzir isso - a sustentabilidade - o temos que fazer é habitar! Que habitar? O habitar é transformar! Na teoria sistêmica, cada vez que um conjunto de elementos começa a conservar-se em suas relações, abre-se espaço para que tudo mude e todas as relações se conservem. Condição central no sistema. Ximena: Como o que guia o viver humano são os desejos, eles surgem como os sustentáveis na realidade que se vive e que se deseja conservar neste habitar. [...] $\bigcirc$ futuro que deixamos para as crianças é fabricado na convivência. O que vamos deixar para os outros se dá na relação cotidiana.
\end{abstract}

Quando começamos a desenvolver as práticas com os tecidos, percebemos que as crianças começaram a propor outras vivências e explorar o material para além da proposta inicial. Com o tecido tubular foi possível construirmos pontes, fazer túnel, travessias e desafios de equilíbrio. $\mathrm{O}$ tecido elástico permitiu vivências de ginástica, com seus saltos, rolamentos e o trabalho aéreo de "queda livre". Ao longo dessa experiência e com a aquisição dos "tecidos acrobáticos", começamos um trabalho de giro e sustentação, construindo com as crianças outras possibilidades de subida, manobras acrobáticas e apresentação cultural. Todo esse trabalho possibilitou a apresentação de ginástica para as demais turmas do CMEI Denizart Santos. O conhecimento foi construído junto com as crianças, tornado as práticas significativas para a formação humana que desejávamos alcançar. 


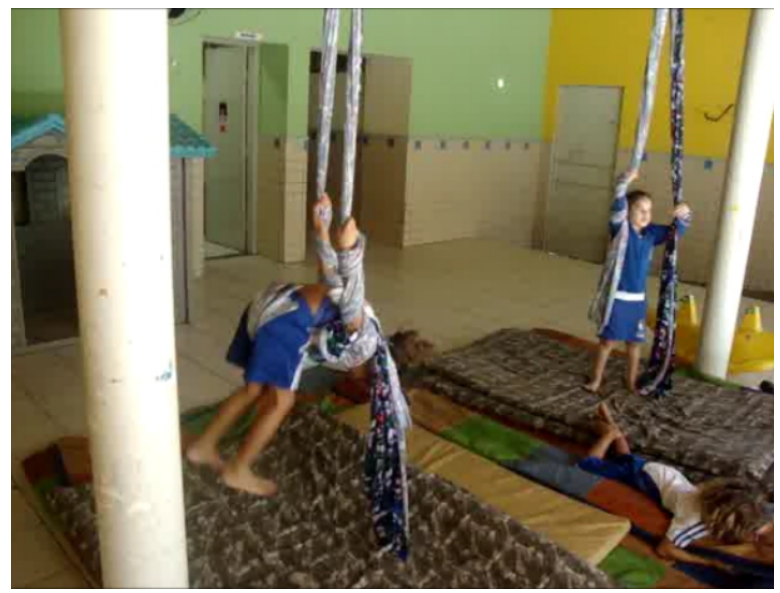

Ao longo do primeiro semestre foi possível trabalharmos os seguintes conhecimentos e temáticas: balanços, violão, basquete, tecidos, pneus, piscina de bolas, cordas, slackline, lençol, túnel em napa, futebol, ginástica, salto em altura, trave, bola de pilates. As crianças a todo o momento interferiram no processo de construção das práticas e deram significados diferentes dos objetivos iniciais. Aprendíamos com elas e modificávamos as práticas, ampliando o universo de possibilidades de movimentos e apropriações da cultura corporal.

No decorrer do $2^{\circ}$ semestre as atividades seguiram um ensino em "multiníveis", com organizações em grupos de alunos, respeitando o nível de aprendizagem de cada um como: présilábico, silábico com ou sem valor sonoro, silábico alfabético e alfabético. Essa metodologia está pautada nos estudos de Porter (1997, p.44), o qual nos diz que:

Essa forma de trabalho favorece um currículo comum a todos os alunos, garante um ensino em níveis diversificados, possibilitando assim, aos alunos que apresentam níveis diferenciados a oportunidade de se envolverem de forma relevante nas atividades de sala de aula. 


\section{Considerações e reflexões}

A experiência compartilhada poderia indicar o processo interdisciplinar entre diferentes especialistas na educação infantil, contudo, acreditamos que essa experiência educativa reconhece as especificidades desse nível da educação básica, na qual o trabalho com as crianças é somativo. Dito de outra forma, o atendimento educacional à criança de 0 a 6 anos exige ações conjuntas, parcerias na atuação entre os diferentes profissionais dessa instituição. É o que nos propõe Ayoub (2001, p. 56):

[...] mas em professoras(es) de educação infantil que, juntas(os), com as suas diversas especificidades de formação e atuação, irão compartilhar seus diferentes saberes docentes para a construção de projetos educativos com as crianças. Nesse sentido, poderíamos pensar também em parceria com as crianças, considerando e valorizando as suas experiências e interesses.

Vygotsky (1984), Wallon (2007) contribuem com a perspectiva formativa do brincar. Esses autores nos ajudam a pensar uma prática pedagógica que reconhece a criança como sujeito ativo na sua constituição. Para além, nos dão pistas para mediarmos o conhecimento sistematizado da humanidade, iniciando esses novos sujeitos em um mundo que é dinâmico, exigindo novas formas de nos relacionarmos com a natureza e reinventarmos outros modos de ser e estar vivendo em sociedade.

Quais linguagens eles desenvolveram? Aceitamos a perspectiva que Gonçalves e Antonio (2007) defendem, provocando-nos a buscar novas formas de saberes-fazeres na educação infantil:

\footnotetext{
Por vezes quando falamos em linguagem é comum remetermos à linguagem verbal e escrita, igualmente fundamental para o desenvolvimento infantil, no entanto, algumas professoras acabam priorizando essas duas formas de linguagem na educação das crianças, em detrimento de outras, privando-as de novas vivências, novas experiências que ampliem seus conhecimentos. Nesse sentido, a educação infantil vem buscando superar esse entendimento de linguagem e considerando que a criança se comunica e se expressa por meio de múltiplas linguagens [...] (GONÇALVES; ANTÔNIO, p. 87, 2007).
}

É comum percebermos o que elas aprenderam e relatarmos os avanços alcançados na linguagem oral, na escrita e leitura, no comportamento e nas relações interpessoais. Contudo, sendo as crianças sujeitos participantes no/do processo educacional, aprendemos com elas que o conhecimento é compartilhado, cabendo aos sujeitos dar sentidos a esse tempo na "escola"; que a vida se reinventa e nos convida a seguir, acreditando no novo que as crianças representam; a aceitar as diferenças que nos unem; a reconhecer nosso compromisso na construção de um mundo melhor com as crianças e suas famílias; elas nos ensinam a respeitar o outro, no exercício da cidadania, da 
docência.

Reconhecemos, conforme Gleizer (2005), a perspectiva de Espinosa sobre os afetos que foram vivenciados nesse tempo no CMEI:

Por afeto (affectum) entendo as afecções (affectiones) do corpo, pelas quais a potência de agir desse corpo é aumentada ou diminuída, favorecida ou entravada, assim como as ideias dessas afecções. Quanto, por conseguinte, podemos ser a causa adequada de uma dessas afecções, por afeto entendo uma ação; nos outros casos, uma paixão (Espinosa apud Gleizer, 2005, p. 33).

O agir das crianças é sempre um desafio ao fazer docente, exigindo-se "jogo de cintura" para conduzir o processo educacional ao qual estamos submetidos. Ao mesmo tempo em que estimulávamos a criatividade e autonomia, exigia-se a concentração e a atenção delas; sempre que caminhávamos no sentido de potencializar o fazer das crianças, também ocorria o entrave das ações dos corpos infantis. As ações educativas foram encontros, bons ou maus encontros para nós professores e, também, para as crianças. 
Referências

ALVES, Rubem. A alegria de ensinar. Campinas, SP: Papirus, 2000.

AYOUB, Eliana. Reflexões sobre a educação física na educação infantil. Revista Paulista de Educ. Fís., São Paulo, supl.4, p.53-60, 2001. 2005.

GLEIZER, Marcos André. Espinosa e a afetividade humana. Rio de Janeiro: Jorge Zahar,

GONÇALVES, Cristiane Januário; ANTÔNIO, Débora Andrade. As múltiplas linguagens no cotidiano das crianças. Revista Zero a Seis, n. 16, p. 85-108, 2007.

NICOLA, José de; CHIARION, Rosalina Acedo. Livro de alfabetização. São Paulo: Scipione, 1996.

PORTER, Gordon. Organização das escolas: conseguir o acesso e a qualidade através da inclusão. In: AINSCOW, Mel; et al. Caminhos para as escolas inclusivas. Lisboa: Instituto de Inovação Educacional, 1997.p. 33-48.

ROMESIN, Humberto Maturana; DAVILA Y, Ximena Paz. Conferência: Ética e desenvolvimento sustentável: caminhos para a construção de uma nova sociedade. Revista Psicologia e Sociedade, vol.16, n.3, p. 102-110, 2004.

VYGOTSKY, Lev S. Formação Social da Mente. São Paulo: Martins Fontes, 1984.

WALLON, Henri. A evolução psicológica da criança. São Paulo: Martins Fontes, 2007. 